DOI 10.37882/2223-2982.2021.08.14

\title{
НАУЧНОЕ СОДЕРЖАНИЕ ТЕРМИНА «ЛАКУНА» В РОССИЙСКОЙ И КИТАЙСКОЙ ТЕОРИИ ПЕРЕВОДА В СОПОСТАВИТЕЛЬНОМ АСПЕКТЕ
}

\section{SCIENTIFIC CONTENT \\ OF THE TERM "LACUNA" IN RUSSIAN AND CHINESE THEORY OF TRANSLATION IN A COMPARATIVE ASPECT}

\section{Du Xin \\ N. Chulkina}

Summary: The article is devoted to a comparative analysis of the content of the term «lacuna» in the Russian and Chinese languages and lies at the intersection of translation studies, cultural linguistics and linguistics. The relevance of the research topic is primarily due to the importance of establishing intercultural communication, which has a positive effect on cooperation between Russia and China. In addition, the relevance is determined by the need to study the translation aspect, within which not only the linguistic specificity is important, but also the linguistic and cultural features of languages. The purpose of the study is to identify the specifics of the scientific content of the term «lacuna» in the Russian and Chinese theory of translation in a comparative aspect. In conclusion, the author notes that the lacunae in the Chinese and Russian languages are not limited only to lexical voids. Lacunae are also present at various levels of the language: morphological, grammatical, phonetic, morphemic, and syntactic.

Keywords: theory of translation, Russian and Chinese, "lacuna", equivalentless vocabulary, lexical voids, comparative analysis, extralinguistic factors.
$\mathrm{O}$ дной из актуальных и в то же время недостаточно изученных на сегодняшний день проблем в области теории перевода является проблема определения феномена лакунарности в рамках сопоставления русского и китайского языков. Обусловлено это, прежде всего, ростом межнациональных связей между Россией и Китаем, важностью налаживания межкультурной коммуникации, положительно сказывающейся на сотрудничестве двух стран, а также необходимостью исследования переводческого аспекта, в рамках которого имеет значение не только лингвистическая специфика, но и лингвокультурологические особенности языков. Интерес к такому явлению, как лакунарность (лингвистическая пустота), появился во второй половине XX века, однако, несмотря на многообразие работ по данной теме, существует множество вопросов, нуждающихся в проработке, а также в дополнении теории межкультурной коммуникации. Актуальность и недостаточная изученность

\author{
Ду Синь \\ Аспирант, Российский университет дружбы народов \\ 1281664590@qq.com \\ Чулкина Нина Леонидовна \\ Д.филол.н., профрессор, Российский университет \\ дружбы народов \\ nina.chulkina@yandex.ru
}

Аннотация: Статья посвящена сравнительному анализу содержания термина «лакуна» в русском и китайском языкознании и лежит на стыке переводоведения и лингвокультурологии. Актуальность темы обусловлена, прежде всего, важностью налаживания межкультурной коммуникации, положительно сказывающейся на сотрудничестве России и Китая, и необходимостью исследования переводческого аспекта, в рамках которого имеет значение не только лингвистическая специфика, но и лингвокультурологические особенности языков. Цель работы заключается в выявлении специфики научного содержания термина «лакуна» в российской и китайской теории перевода в сопоставительном аспекте. В заключении авторами отмечается, что лакуны В китайском и русском языках не ограничиваются только лексическими пустотами, но также присутствуют и на различных уровнях языка: морфологическом, грамматическом, фонетическом, морфемном, синтаксическом.

Ключевые слова: теория перевода, русский и китайский языки, термин "лакуна", безэквивалентная лексика, лексические пустоты, сопоставительный анализ, экстралингвистические факторы. феномена лакунарности определили цель данной работы - выявить специфику научного содержания термина «лакуна» в российской и китайской теории перевода в сопоставительном аспекте.

Термин «лакуна» в контексте переводоведения впервые был употреблен канадскими лингвистами Ж.-П. Вине и Ж. Дарбельне [4, с. 23]. Традиционно под термином «лакуна» понимается отсутствие какой-либо лексической единицы в одном языке при наличии ее в другом языке [1]. В современном переводоведении лакуна рассматривается как двусторонняя единица, сформированная под влиянием культурных и лингвистических факторов [2, с. 300]. Существуют следующие проблемы при передаче лакун: отсутствие в принимающем языке эквивалента из-за отсутствия у носителей языка-источника обозначаемого объекта (безэквивалентная лексика); потребность в передаче не только семантического значения, 
но и культурных коннотаций. Процесс преодоления этих трудностей называется элиминированием лакун (заполнение - раскрытие понятия, принадлежащего иной культуре; компенсация - фиксация лакуны в совокупности с компенсатором, т.е. описанием, компенсирующим отсутствующее в языке словом). Переводчик в случае работы с лакунами в процессе перевода как акта коммуникации выступает не только как специалист, владеющий двумя языками, но и межкультурным посредником, который должен учитывать не только особенности языка, но и экстралингвистические факторы, чтоб получить адекватный перевод.

Лакуны обнаруживаются на различных уровнях китайского и русского языков, однако могут не осознаваться носителями языка, обнаруживаясь лишь в сопоставительном анализе, и являются факторами образования акцента, улавливаемого носителями языка в речи изучающего иностранный язык. Фонетические лакуны подразумевают отсутствие определенной фонемы в языке (в китайском языке отсутствуют фонемы «р» и «ы» (существует неразличие букв «р» и «л»), в русском - фонемы «r» и «ng»). Морфемные лакуны состоят в различии составных частей слова: в русском языке это префиксы, корни, суффиксы, интерфиксы, флексии и постфиксы, в то время как в китайском языке существуют только корни, префиксы, суффиксы и полусуффиксы. На морфологическом уровне лакуны проявляются в том, что в китайском языке морфологические показатели определяются только в контексте, однако в русском языке возможно определить падеж, число и род единичного слова, не вписанного в текст. Лексические лакуны китайского и русского языков делятся на мотивированные (отсутствие реалии, т.е. в принимающем языке данной реалии не существует; например, российское слово «дача» не имеет эквивалента в китайском языке) и немотивированные (отсутствие плана выражения для существующей реалии; например, в китайском языке утро делится на три части (утро перед рассветом, раннее утро, утро до полудня), когда как в русском языке данные реалии лексически не дифференцируются) [5, с. 112]. Грамматические лакуны включают в себя отсутствие грамматических категорий, классов и форм (в китайском языке отсутствует число, падеж, склонение и т.д.). На синтаксическом уровне лакуны обнаруживаются при сопоставлении предложений, что составляет проблему в процессе изучения языка (в китайском языке, например, глагол-связка «быть» является обязательным и непропускаемым элементом предложений по типу «ромашка белая» [2]).

Помимо классификаций лакун по разным уровням языка, китайские и российские лингвисты выделяют разные виды лакун, которые, в свою очередь, не отличаются таксономической строгостью. Образованию лакун между китайским и русским языками способствуют такие факторы, как геополитика (влияние географии, расположения стран, климатических особенностей на формирование культурных лакун), уклад жизни (различия ведения быта разными народами), история и религия (православие в России и конфуцианство, буддизм и даосизм в Китае), литература (литературные образы, вызывающие разные ассоциации, разные культовые произведения и т.д.) [6]. Данные факторы способствовали созданию классификаций. Российские ученые выделяют такие лакуны, как этнографические, ассоциативные, лексические. Китайские ученые выделяют следующие виды лакун: названия предметов действительности, литературные крылатые выражения (цитаты из литературных источников), религиозные изречения, философские изречения [5, с. 110]. Наблюдаются различия в формулировке видов лакун при схожем содержании.

Этнографические лакуны, выделяемые российскими переводоведами, исходят из экстралингвистических факторов, требующих от переводчика знаний о культуре и быте как носителей китайского языка, так и носителей русского языка. Эти лакуны составляет лексика, обозначающая реалии, не существующих в иной культуре: наименования единиц измерения длины, количества, веса (尺/chi - 0,32 метра, китайская единица длины); наименования, относящиеся к традициям, быту; названия еды и напитков (粽子/zhòngzi - обёрнутое тростниковыми листьями кушанье из клейкого риса); названия жилища и его частей, а также нетрадиционных мест для жилья (四合院 /sìhéyuàn - традиционный специфичный тип китайской застройки); названия музыкальных инструментов, танцев (二胡 /Ėrhú - струнный инструмент эрху); названия предметов одежды, обуви (中山装/ Zhōngshānzhuāng - мужской френч наподобие военного кителя); названия явлений и реалий природы (风沙/ fēngshā - летучий песок); названия праздников и игр (麻 将 /Májiàng - маджонг (игра в кости)); названия денежных единиц (元/yuán - юань); названия династий императоров, а также предметов, относящихся к императору; названия нормативных документов (绿 皮书/Lüpíshū - общедоступный сборник официальных документов, отчетов и т.д.). В классификации лакун китайских переводоведов содержанию типа «этнографическая лакуна» соответствует тип «названия предметов действительности» [2, с. 301], также имеющий в своем составе вышеперечисленные категории с некоторыми добавлениями (единицы веса, длины, титулы, профессии, инструменты, одежда, обувь и т.д.).

Следующий тип лакун, выделяемый в отечественной теории перевода - ассоциативные лакуны, представляющие собой слова и выражения с национальным подтекстом, вызывающим определенные ассоциации и передающие фоновую информацию. Сюда входят: антропонимы (习近平/Xí Jinpíng), топонимы (廣州/Guăngzhōu), этнонимы (苗/ Miáo - группа народов в южном Китае), языковые аллюзии (成语/chéngyŭ -идиома; 歇后语/xiehouyu - pe- 
чения с усеченной концовкой - недоговорки, иносказания; 惯用语/guànyòngyǔ - привычное выражение, 警句/ jǐngjù - афоризм) [7, с. 101]. В китайской теории перевода данному типу соответствуют литературные крылатые выражения (цитаты из классических литературных источников), а также условно - философские изречения и религиозные изречения, являющиеся близкими по своему происхождению в китайской культуре (в некоторых исследованиях объединяются в одну группу лакун - религиозно-философские изречения).

Лексические лакуны в различных исследованиях имеют разное определение; так, некоторые исследователи определяют содержание лексической лакуны отсутствующими в принимающей культуре реалиями/понятиями/ предметами, существующими в культуре носителей иного языка [8]. Исходя из широкого определения, можно отнести к лексическим лакунам вышеописанные виды (этнографические и ассоциативные лакуны). Однако в данном исследовании такие лакуны рассматриваются также и в более узком значении, т.е. в связи со смыслом слова, с соотношением вида и рода. Лексическая лакуна в этом определении не имеет аналога в китайской теории перевода, являясь более частным случаем образования лексических пустот. В отличие от лексических лакун, этнографические и ассоциативные лакуны не могут быть выявлены с достаточной точностью, но более интересны и показательны с точки зрения репрезентации культуры носителя языка [3, с. 29]. Сохранение таких лакун в тексте может оказать как положительное влияние на перевод (сохранение аутентичности источника оригинала и культуры, к которой он принадлежит), но также и негативный эффект (недостижение прагматических целей, непонимание реципиентом текста)).

Таким образом, было выявлено, что лакуны в китайском и русском языках не ограничиваются только лексическими пустотами (отсутствующими словами, уникальными для иной культуры выражениями и т.д.), но также присутствуют и на различных уровнях языка (морфологический, грамматический, фонетический, морфемный, синтаксический), что учитывается при осуществлении перевода и адаптации лакунарных понятий. В китайской и российской теории перевода существуют различные формулировки классификаций видов лакун, которые, однако, пересекаются в содержании и могут быть объединены в единую классификацию (лакуны лексические, этнографические, ассоциативные, литературные и религиозно-философские). Отмечается более абстрактный характер классификации в российской теории перевода, нежели в китайской классификации, где виды определены более конкретно и называют конкретное явление культуры (литературные выражения, названия предметов действительности, религиозные и философские изречения; тогда как в отечественной теории перевода в ассоциативные лакуны могут входить как литературные крылатые выражения, так и религиозно-философские). Данные классификации нуждаются в дальнейшем развитии с точки зрения современной лингвистики.

\section{ЛИТЕРАТУРА}

1. Абдуразакова, Ш.Р. Межъязыковые лакуны и способы их перевода / Ш.Р. Абдуразакова // Филология и лингвистика в современном обществе: матер. I Междунар. науч. конф. (г. Москва, май 2012 г.). - М.: Ваш полиграф. партнер, 2012. - С. $97-99$.

2. Гао Шуай. Лакуны в китайском и русском языках: сопоставительный анализ / Гао Шуай // Сб. науч. тр. Ангарского гос. тех. ун-та. - 2020. - Т.1; № 17. C. 299-302.

3. Глазачева, Н.Л. Еще раз о типологии межъязыковых лакун (на матер. китайского и русского языков) / Н.Л. Глазачева // Лакуны в языке и речи: сб. науч. тр. - Благовещенск, 2003. - С. 28-33.

4. Ибрагимова, К.Г. О значении понятий «лакунарность» и «лакуна» для теории и практики перевода / К. Г. Ибрагимова // ФИЛОLOGOS. - 2016. - № 28(1). C. 22-26.

5. Х Хорошавина, А.Г. К вопросу о классификации лакун в современном русском и китайском переводоведении / А.Г. Хорошавина, А.А. Сулейманова, Л.А. Биккинина // БГЖ. - 2013. - № 4(5). - С. 110-114.

6. Чан Сянюй. 0 культурных лакунах в международной коммуникации на материалах русского и китайского языков / Чан Сянюй // Наука, образование и культура. - 2017. - № 9(24). - С. 39-43.

7. Щичко, В.Ф. Теория и практика перевода / В.Ф. Щичко. - М.: Восток-Запад, 2004. - 223 с.

8. Ягуфаров, Р.А. Лексические лакуны китайского языка: переводческий аспект / Р.А. Ягуфаров // Евразийское научное объединение. - 2018. - № 5-3(39). C. 144-146.

(с) Ду Синь (1281664590@qq.com), Чулкина Нина Леонидовна (nina.chulkina@yandex.ru).

Журнал «Современная наука: актуальные проблемы теории и практики» 